\title{
Sustainable Transportation
}

\section{DOE Issues Final Rule for Section 133 of the Energy Independence Act}

The U.S. Department of Energy (DOE) has issued

a final rule under Section 133 of the Energy

Independence and Security Act of 2007 (EISA). The

rule is published in the March 21, 2014, Federal Register

at $h t t p: / / w W w . g p o . g o v / f d s y s / p k g / F R-2014-03-21 /$

pdf/2014-06044.pdf (79 FR 15881).

\section{Impact of the Rule}

The final rule focuses on Section 133 of EISA, which directs DOE to allocate credits under the Alternative Fuel Transportation Program to covered state government and alternative fuel provider fleets that acquire various types of electric drive vehicles, and/or that invest in emerging technologies related to those vehicles, qualified alternative fuel infrastructure, and qualified alternative fuel non-road equipment. Some of the vehicles that Section 133 identifies already meet the Energy Policy Act of 1992's (EPAct) definition of an alternative fuel vehicle (AFV) and are already counted toward a fleet's compliance with its annual AFV-acquisition requirements. Under the rule, DOE has established credit allocations for covered fleets that acquire the Section 133-identified vehicles that do not meet the program's definition of an AFV, and for covered fleets that make the investments identified in Section 133.

\section{Credits and Changes}

DOE has established the following credit allocation levels under the program's Standard Compliance method for the acquisition of the Section 133-identified vehicles that do not meet the program's definition of an AFV:

- Hybrid electric vehicles (HEVs): one-half credit

- Plug-in electric drive vehicles: one-half credit

- Fuel cell electric vehicles: one-half credit

- Medium- or heavy-duty HEVs: one-half credit (credit available only after the fleet has met its light-duty AFV-acquisition requirements)

- Neighborhood electric vehicles (NEVs): one-fourth credit (note that an NEV can never qualify as an AFV).

\section{Key Facts}

- Under the final rule, the new credit allocations apply to vehicle acquisitions and investments made in model year 2014 and future model years.

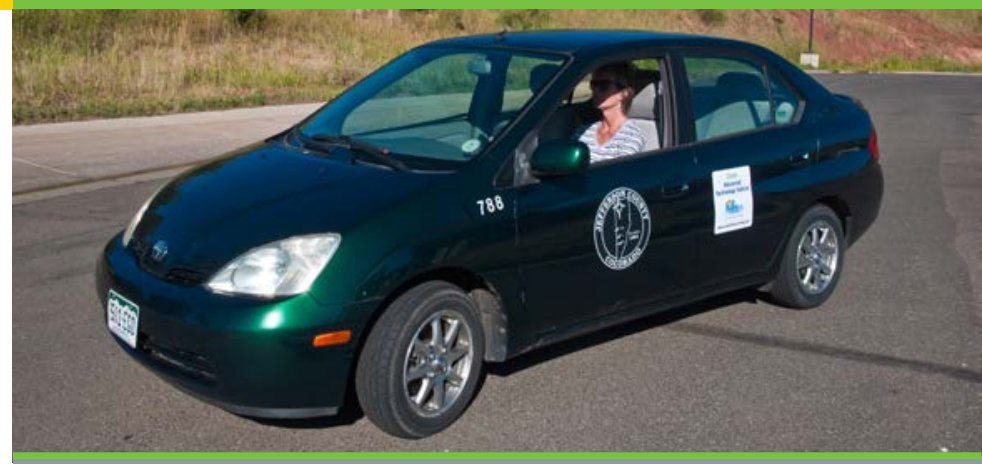

DOE is establishing credit allocation levels for electric drive vehicles that do not otherwise qualify as alternative fuel vehicles. Photo by Pat Corkery, NREL 18150

- Section 133-identified vehicles that already qualify as AFVs (e.g., battery electric vehicles) are already counted as such under the program.

- Under the rule, DOE will allocate less than a full AFV credit to Section 133 vehicles that are non-AFVs because non-AFVs have less potential than AFVs to affect petroleum replacement, a goal of EPAct and the program.

- NEVs as well as medium- or heavy-duty HEVs and AFVs that a covered fleet acquires are not factored into the fleet's light-duty vehicle-acquisition count, which is the basis for determining the fleet's annual AFV-acquisition requirements.

\section{Credits for Investments}

DOE has also established the following credit allocation levels for the following actions by covered fleets:

- DOE will allocate credit to covered fleets for their investments in qualified alternative fuel infrastructure (i.e., fueling or charging stations) and alternative fuel non-road equipment (e.g., mobile construction or material/cargo handling equipment) with one credit for every $\$ 25,000$ invested and a maximum of 5 credits per fleet per model year, except for investments in public alternative fuel infrastructure, for which the maximum number of credits that may be earned per fleet per model year is 10 .

- For investments in emerging technologies (i.e., pre-production electric drive vehicles), two credits will be allocated for the first $\$ 50,000$ invested and one credit for each $\$ 25,000$ thereafter with a 5-credit maximum per fleet per model year. Fleets should seek credits for their investments in the model year in which the infrastructure, non-road equipment, or emerging technology is placed into service.

The final rule also contains modifications to the program's exemption process and the Alternative Compliance option, as well as several other amendments to make the program regulations clearer. These modifications are effective as of April 21, 2014. 